\title{
Impact of enhanced vertical mixing on marine biogeochemistry: lessons for geo-engineering and natural variability
}

\author{
S. Dutreuil ${ }^{1,2}$, L. Bopp ${ }^{1}$, and A. Tagliabue ${ }^{1}$ \\ ${ }^{1}$ Laboratoire des Sciences du Climat et de l'Environnement, IPSL-CEA-CNRS-UVSQ Orme des Merisiers, Bat 712, \\ CEA/Saclay, 91198, Gif sur Yvette, France \\ ${ }^{2}$ Ecole Normale Supérieure, 45 rue d'Ulm, 75005 Paris, France
}

Received: 28 October 2008 - Published in Biogeosciences Discuss.: 5 January 2009

Revised: 2 April 2009 - Accepted: 24 April 2009 - Published: 25 May 2009

\begin{abstract}
Artificially enhanced vertical mixing has been suggested as a means by which to fertilize the biological pump with subsurface nutrients and thus increase the oceanic $\mathrm{CO}_{2}$ sink. We use an ocean general circulation and biogeochemistry model (OGCBM) to examine the impact of artificially enhanced vertical mixing on biological productivity and atmospheric $\mathrm{CO}_{2}$, as well as the climatically significant gases nitrous oxide $\left(\mathrm{N}_{2} \mathrm{O}\right)$ and dimethyl sulphide (DMS) during simulations between 2000 and 2020. Overall, we find a large increase in the amount of organic carbon exported from surface waters, but an overall increase in atmospheric $\mathrm{CO}_{2}$ concentrations by 2020 . We quantified the individual effect of changes in dissolved inorganic carbon (DIC), alkalinity and biological production on the change in $p \mathrm{CO}_{2}$ at characteristic sites and found the increased vertical supply of carbon rich subsurface water to be primarily responsible for the enhanced $\mathrm{CO}_{2}$ outgassing, although increased alkalinity and, to a lesser degree, biological production can compensate in some regions. While ocean-atmosphere fluxes of DMS do increase slightly, which might reduce radiative forcing, the oceanic $\mathrm{N}_{2} \mathrm{O}$ source also expands. Our study has implications for understanding how natural variability in vertical mixing in different ocean regions (such as that observed recently in the Southern Ocean) can impact the ocean $\mathrm{CO}_{2}$ sink via changes in DIC, alkalinity and carbon export.
\end{abstract}

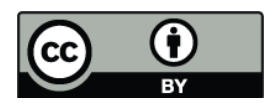

Correspondence to: L. Bopp

(laurent.bopp@1sce.ipsl.fr)

\section{Introduction}

In the context of rising anthropogenic emissions of carbon dioxide $\left(\mathrm{CO}_{2}\right)$ and increasing atmospheric $\mathrm{CO}_{2}$ concentrations, the ocean is a significant $\mathrm{CO}_{2}$ sink (on the order of $2 \mathrm{Pg} \mathrm{yr}^{-1}$ over the 1990s (Denman, et al., 2008)). The socalled biological pump is one important process by which the ocean can take up atmospheric $\mathrm{CO}_{2}$ and results from the surface water fixation of $\mathrm{CO}_{2}$ into organic matter during photosynthesis and subsequent sinking and remineralisation at depth (Volk and Hoffert, 1985). Accordingly, some geoengineering proposals seek mitigate for rising atmospheric $\mathrm{CO}_{2}$ by increasing the efficiency of the biological pump and hence also the oceanic sink for atmospheric $\mathrm{CO}_{2}$. In the past, such proposals tended to focus on the artificial fertilization of ocean productivity by the micronutrient iron $(\mathrm{Fe})$ (e.g., Markels and Barber, 2000; Leinen, 2008; Lampitt et al., 2008), which limits phytoplankton productivity in certain oceanic regions (such as the Southern Ocean) (Boyd et al., 2000). Although mesoscale field experiments have shown that the addition of $\mathrm{Fe}$ can augment phytoplankton biomass, the increased flux of organic carbon to deep waters (termed "export") is often very difficult to verify in situ (de Baar et al., 2005; Boyd et al., 2007). In addition, experiments with numerical models have shown that the links between $\mathrm{Fe}$, phytoplankton productivity, carbon export and atmospheric $\mathrm{CO}_{2}$ are by no means straightforward (e.g., Arrigo and Tagliabue, 2005; Aumont and Bopp, 2006), and might have unintended adverse consequences for ocean ecosystems and climate (Jin and Gruber, 2005; Cullen and Boyd, 2008).

A more recent proposal to increase the strength of the ocean's biological pump concerns the artificial mixing of nutrient-rich deep waters with nutrient-poor surface waters

Published by Copernicus Publications on behalf of the European Geosciences Union. 
via mechanical pipes (Lovelock and Rapley, 2007). In a nutshell, the idea seeks to mimic the natural upwelling systems that are typified by high levels of productivity. However, as seen for Fe, the practicalities are not likely to be straightforward. For example, deep waters are rich in both nutrients and respired $\mathrm{CO}_{2}$, which can outgas to the atmosphere and might offset any gains from the fertilization of productivity (Shepherd et al., 2007). In addition, the partial pressure of $\mathrm{CO}_{2}$ $\left(p \mathrm{CO}_{2}\right)$ in surface waters, which drives the rate of exchange with the atmosphere (in addition to winds), is a positive function of the concentration of total dissolved inorganic carbon (DIC) and sea surface temperature, and a negative function of alkalinity (Zeebe and Wolf-Gladrow, 2001). Artificial mixing or artificial upwelling will directly impact the profiles of temperature, DIC and alkalinity, while the secondary effects on biological productivity will also influence surface concentrations of DIC and alkalinity. Notable associated effects include potential modifications of ocean food webs resulting from the fertilization of ocean productivity, which often alters the dominant phytoplankton species (e.g., de Baar et al., 2005 ), or potential modifications of $\mathrm{N}_{2}$-fixation that has been discussed recently and for which the net effect of an artificial upwelling remains unclear (Karl and Letelier, 2008; Fennel, 2008). Moreover, the concentrations of other climatically important gasses, such as nitrous oxide $\left(\mathrm{N}_{2} \mathrm{O}\right)$ and dimethyl sulphide (DMS) will probably also be altered by the deliberate enhancement of ocean mixing. Accordingly, a complex set of interactions will ultimately resolve the impact of a suite of pipes on atmospheric $\mathrm{CO}_{2}$ in a given region of the ocean.

Testing and quantifying the net effect of such a widespread deployment of ocean pipes on atmosphere-ocean fluxes of $\mathrm{CO}_{2}$, as well as the additional perturbations to ocean ecosystems and other climatic gases, in the field would be a significant challenge. Nevertheless, mechanistic models of ocean biogeochemistry that represent the requisite processes in a relatively detailed fashion can provide a valuable framework within which to address these questions. In doing so, we can also learn about the impact of natural variability in ocean mixing (typically driven by climate oscillations) on the ocean carbon cycle.

In this study, we mimic the effect of an array of ocean pipes in an ocean general circulation and biogeochemistry model (OGCBM) and address the regional and global impact on carbon export, $\mathrm{CO}_{2}$ fluxes, as well as phytoplankton species composition, $\mathrm{N}_{2} \mathrm{O}$, and DMS. In order of importance, we find that the overall effect of artificially mixing the ocean is a function of the mixing of 1) DIC, 2) alkalinity, and 3) nutrients and associated biological production. Notwithstanding regional heterogeneity, the mixing of natural DIC is the dominant effect on atmospheric $\mathrm{CO}_{2}$ increase which is then decoupled from the elevated biological productivity. DMS fluxes to the atmosphere increase in line with changes in carbon export, whereas the oceanic source of $\mathrm{N}_{2} \mathrm{O}$ responds to the interactions between export and mixing in governing subsurface oxygen $\left(\mathrm{O}_{2}\right)$ concentrations.

\section{Methods}

\subsection{Biogeochemical model description}

In this study, we use the Pelagic Interaction Scheme for Carbon and Ecosystem Studies (PISCES) ocean biogeochemical model. As a detailed description of the model parameterizations is given in Aumont and Bopp (2006), the model is only briefly presented here. The model has 24 compartments, including four living pools: two phytoplankton size classes/groups (nanophytoplankton and diatoms) and two zooplankton size classes (microzooplankton and mesozooplankton). Phytoplankton growth can be limited by five different nutrients: nitrate, ammonium, phosphate, silicate and iron. Diatoms differ from nanophytoplankton by their need for $\mathrm{Si}$, a higher requirement for $\mathrm{Fe}$ and a higher halfsaturation constant (because of their larger mean size). For all living compartments, the ratios between $\mathrm{C}, \mathrm{N}$ and $\mathrm{P}$ are kept constant. On the other hand, the internal concentrations of $\mathrm{Fe}$ for both phytoplankton groups and $\mathrm{Si}$ for diatoms are prognostically simulated as a function of nutrients and light. There are three nonliving compartments: semilabile dissolved organic matter (with remineralisation timescales of several weeks to several years), small and large sinking particles. The two particle size classes differ in their sinking speeds $(3 \mathrm{~m} / \mathrm{d}$ for the small size class and 50 to $200 \mathrm{~m} / \mathrm{d}$ for the large size class). While constant Redfield ratios are imposed for $\mathrm{C} / \mathrm{N} / \mathrm{P}$, the iron, silicon and calcite pools of the particles are fully simulated. As a consequence, their ratios relative to organic carbon are allowed to vary.

In addition to the version of the model used in Aumont and Bopp (2006), we also include here a prognostic module computing DMS seawater concentrations and DMS airsea fluxes. This module is described in detail in Bopp et al. (2008). In brief, particulate dimethylsulfonopropionate (pDMSP), the main precursor of DMS in seawater, is computed from the carbon biomass of the two phytoplankton groups (diatoms and nanophytoplankton) via group-specific sulphur (DMSP)-to-carbon (S/C) ratios. Then, pDMSP is released to the water column as dissolved DMSP (dDMSP) via three different processes: grazing by zooplankton, exudation by phytoplankton, and phytoplankton cell lysis. Once released into water, we assume that bacterial activity instantaneously transforms dDMSP into DMS, with a dDMSP-toDMS yield computed as a function of the bacterial nutrient stress. Simulated DMS losses are due to bacterial and photochemical processes and ventilation to the atmosphere. For ventilation to the atmosphere, the gas exchange coefficient, $\mathrm{kg}$, is computed using the relationship of Wanninkhof (1992) and the Schmidt number for DMS calculated following the formula given by Saltzman et al. (1993).

Finally, we also include here the module of the oceanic $\mathrm{N}_{2} \mathrm{O}$ proposed by Suntharalingham et al. (2000) to compute $\mathrm{N}_{2} \mathrm{O}$ seawater concentrations and air-sea fluxes. $\mathrm{N}_{2} \mathrm{O}$ is treated as a non conserved tracer, where the tracer equation 
is as follows:

$$
\begin{aligned}
\frac{\partial}{\partial t}\left[\mathrm{~N}_{2} \mathrm{O}\right]= & -\nabla \cdot\left(\left[\mathrm{N}_{2} \mathrm{O}\right] \boldsymbol{v}\right)+\nabla_{z} \cdot\left(k_{z} \nabla_{z}\left[\mathrm{~N}_{2} \mathrm{O}\right]\right) \\
& +\nabla_{l} \cdot\left(k_{l} \nabla_{l}\left[\mathrm{~N}_{2} \mathrm{O}\right]\right)+J_{\mathrm{N}_{2} \mathrm{O}}+F_{\mathrm{N}_{2} \mathrm{O}}
\end{aligned}
$$

The first three terms on the right-hand side represent advection, vertical and lateral diffusion, $J_{\mathrm{N}_{2} \mathrm{O}}$ represents the biological sources of $\mathrm{N}_{2} \mathrm{O}$ and $F_{\mathrm{N}_{2} \mathrm{O}}$ is the flux of $\mathrm{N}_{2} \mathrm{O}$ across the air-sea interface. We follow Suntharalingham et al. (2000) and we assume no $\mathrm{N}_{2} \mathrm{O}$ production in the euphotic zone $\left(J_{\mathrm{N}_{2} \mathrm{O}}=0\right)$. In the aphotic zone, $\mathrm{N}_{2} \mathrm{O}$ is produced when ammonium is oxidized to nitrate (nitrification pathway) and when organic nitrogen is converted to $\mathrm{N}_{2} \mathrm{O}$ at low $\mathrm{O}_{2}$ concentrations (denitrification pathway). Again, we follow Suntharalingham et al. (2000) and parameterize the $\mathrm{N}_{2} \mathrm{O}$ source term to be a function of the $\mathrm{O}_{2}$ concentration and $\mathrm{O}_{2}$ consumption. $J_{\mathrm{N}_{2} \mathrm{O}}$ is given by

$J_{\mathrm{N}_{2} \mathrm{O}}=\alpha \cdot\left[\mathrm{O}_{2} \cdot\right.$ consumption $]+\beta \cdot f\left(\mathrm{O}_{2}\right) \cdot\left[\mathrm{O}_{2} \cdot\right.$ consumption $]$

where $\alpha$ and $\beta$ are scalar multipliers and $f\left(\mathrm{O}_{2}\right)$ a function of $\left[\mathrm{O}_{2}\right]$ such that $\mathrm{N}_{2} \mathrm{O}$ production is maximum at $\left[\mathrm{O}_{2}\right]=1 \mu \mathrm{mol} / \mathrm{L}$ (denitrification pathway). Values for the scalars $\alpha$ and $\beta$ have been taken from simulation OX.5 of Suntharalingham et al. (2000). $\mathrm{N}_{2} \mathrm{O}$ is lost to the atmosphere via gas exchange, the gas exchange coefficient, $\mathrm{kg}$, being computed using the relationship from Wanninkhof (1992) and the Schmidt number for $\mathrm{N}_{2} \mathrm{O}$.

In order to assess the impact of our mixing experiments on atmospheric concentrations, we use a well-mixed box model of the atmosphere that simulates the evolution of the atmospheric $\mathrm{CO}_{2}$ and $\mathrm{N}_{2} \mathrm{O}$ concentrations.

\subsection{Simulations}

Our OGCBM couples the PISCES model to the dynamical ocean model ORCA2-LIM, which is based on both the ORCA2 global configuration of OPA version 8.2 (Madec et al., 1998) and the dynamic-thermodynamic sea-ice model developed at Louvain-La Neuve (Fichefet and Morales Maqueda, 1997). The ocean model has a mean horizontal resolution of $2^{\circ}$ by $2^{\circ} \cos \phi$ (where $\phi$ is the latitude) with a meridional resolution that is enhanced to $0.5^{\circ}$ at the equator. The model has 30 vertical levels (increasing from $10 \mathrm{~m}$ at the surface to $500 \mathrm{~m}$ at depth); 12 levels are located in the top $125 \mathrm{~m}$.

In this study, we have used the same forcing fields as those of Aumont and Bopp (2006) and run an "offline" version of the PISCES following a very similar experimental design to that described in Aumont and Bopp (2006) and Bopp et al. (2008). We performed a climatological simulation run to quasi-equilibrium (for 3000 years), and then patchy mixing experiments and regional mixing experiments for the subArctic Pacific, the Southern Ocean and the Equatorial Pacific. For all the mixing experiments and in an attempt to mimic the impact of ocean pipes on biogeochemistry, we have increased the vertical diffusivity coefficient $K_{z}$ for all biogeochemical tracers, down to $200 \mathrm{~m}$ (which is in line with the proposed dimensions of mechanical pipes (Lovelock and Rapley, 2000)). Accordingly, all passive tracers are mixed permanently from the surface to at least $200 \mathrm{~m}$, which would be broadly similar in terms of net transport to adding both an artificial upwelling and downwelling velocities of $0.1 \mathrm{~m} / \mathrm{s}$. All the other physical/dynamic forcing variables are unchanged (in particular, we do not simulate any change in the mixed layer depth). For the patchy mixing experiments, the mixing sites are worldwide and represent one grid cell every $20^{\circ}$ in longitude and every $\sim 10^{\circ}$ in latitude. In order to examine the impact of restricting mixing to a larger, but geographically constrained, region we performed "regional mixing experiments" in idealized locations (sub-Arctic Pacific, Southern Ocean, and equatorial Pacific). As such enhanced mixing is enforced for the entire region in question, $30^{\circ} \mathrm{N}$ to $44^{\circ} \mathrm{N}$ and $124^{\circ} \mathrm{W}$ to $154^{\circ} \mathrm{W}, 40^{\circ} \mathrm{S}$ to $60^{\circ} \mathrm{S}$, and $15^{\circ} \mathrm{S}$ to $1^{\circ} \mathrm{N}$ and $74^{\circ} \mathrm{W}$ to $124^{\circ} \mathrm{W}$, for the sub-Arctic Pacific, the Southern Ocean and the Equatorial Pacific respectively. In addition, we also performed a global mixing experiment, where the entire global ocean is mixed to at least $200 \mathrm{~m}$. All experiments are carried out for $20 \mathrm{yrs}$, starting in 2000. Atmospheric $\mathrm{CO}_{2}$ and $\mathrm{N}_{2} \mathrm{O}$ are updated at the end of each year using fossil-fuel emissions (SRES98-A2, Nakisenovic et al., 2000), biospheric carbon fluxes (Dufresne et al., 2002) and the air-sea fluxes from our ocean model for $\mathrm{CO}_{2}$, and $\mathrm{N}_{2} \mathrm{O}$.

\section{Results and discussion}

\subsection{Model mean state}

The objective here is not to present an exhaustive validation of the model results. A detailed description of the model mean state can be found in Aumont and Bopp (2006) for carbon, nutrients and biota and in Bopp et al. (2008) for the DMS cycle. We illustrate here some aspects of the model that are relevant to the present study.

The modeled annual-mean chlorophyll distribution is compared to SeaWiFS satellite observations (Fig. 1a) and the observed patterns are qualitatively reproduced. Chlorophyll concentrations are too low in the subtropical oligotrophic gyres. In the equatorial Pacific and the Southern Ocean, the model reproduces the moderate chlorophyll levels associated with elevated macronutrients (typical of High Nutrient Low Chlorophyll regions). In the Southern Ocean however, the simulated chlorophyll concentrations appear to be too high. In the sub-Arctic Pacific Ocean, chlorophyll concentrations are generally underestimated, mainly because of deficiencies in the modeled ocean dynamics. Global annual-mean primary and export productions amount to 41 and $8 \mathrm{Pg} \mathrm{C} \mathrm{y}^{-1}$, respectively, which is in the range of estimations based on observations (Carr et al., 2006; Schlitzer et al., 2000). 

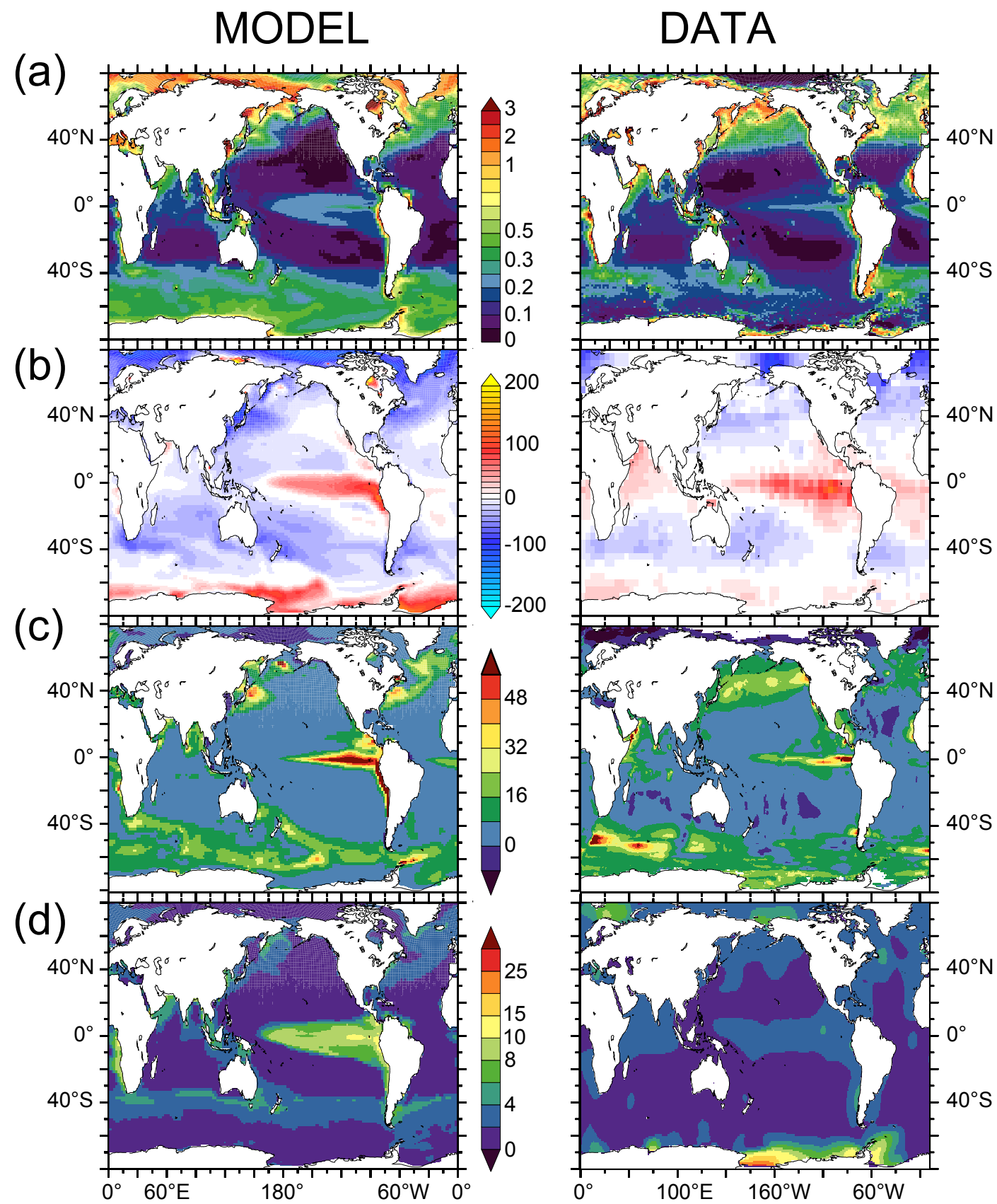

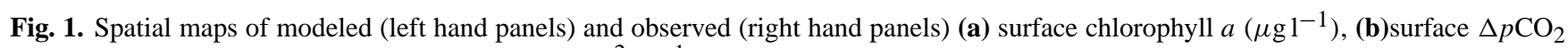
(ppm), (c) the ocean to atmosphere $\mathrm{N}_{2} \mathrm{O}$ flux $\left(\mathrm{g} \mathrm{N} \mathrm{m}^{-2} \mathrm{yr}^{-1}\right)$, and (d) surface DMS (nM).

The modeled annual-mean air-to-sea gradient in $p \mathrm{CO}_{2}$ $\left(\triangle p \mathrm{CO}_{2}\right)$ is compared to the recently published climatology of Takahashi et al. (2008) (Fig. 1b). Again, the observed patterns are well reproduced by the model. Regions with positive $\Delta p \mathrm{CO}_{2}$ (oceanic sources of $\mathrm{CO}_{2}$ to the atmosphere) are in the Equatorial Pacific, the tropical Atlantic, the Arabian sea and along the Antarctic shelves. Regions with negative $\Delta p \mathrm{CO}_{2}$ (oceanic sinks for atmospheric $\mathrm{CO}_{2}$ ) are simulated in the mid-latitudes of all oceanic basins and in the high lat- itudes of the Northern Hemisphere. The annual-mean atmospheric $\mathrm{CO}_{2}$ sink is $2.3 \mathrm{Pg} \mathrm{C}^{-1}$ for $1990-1999$, which is in line with the recent IPCC estimates of $2.2 \pm 0.4 \mathrm{Pg} \mathrm{C} \mathrm{y}^{-1}$ for the same period (Denman et al., 2008).

The modeled annual-mean $\mathrm{N}_{2} \mathrm{O}$ fluxes from the ocean to the atmosphere are compared to the climatology of Nevison et al. (1995, Fig. 1c). The observed patterns are well reproduced by the model. High emissions of $\mathrm{N}_{2} \mathrm{O}$ are predicted in the $40^{\circ} \mathrm{S}-60^{\circ} \mathrm{S}$ band, in the Equatorial Pacific, 


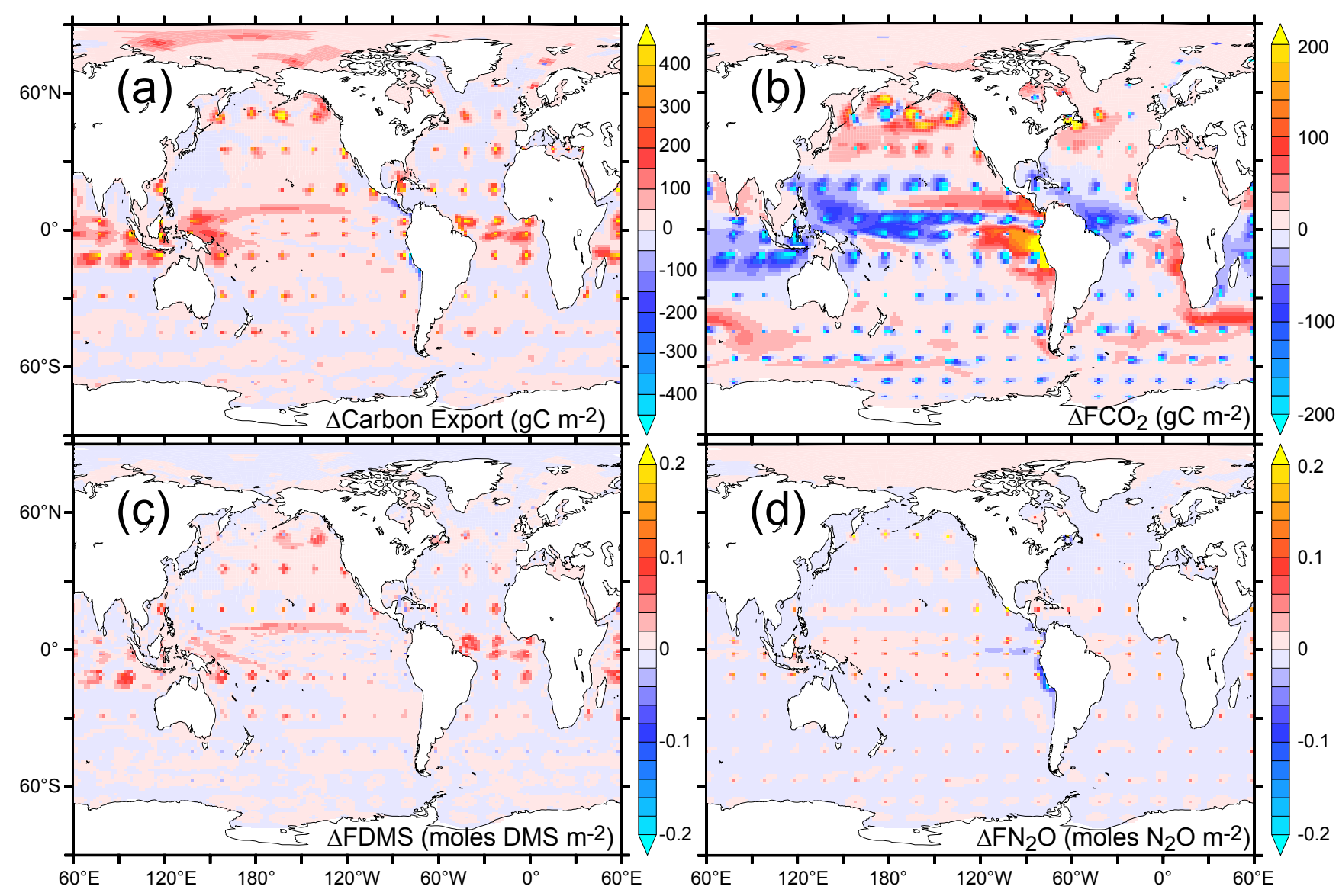

Fig. 2. Spatial maps of the cumulative anomaly (over 20 years) in (a) carbon export $\left(\mathrm{g} \mathrm{C} \mathrm{m}^{-2}\right)$, (b) ocean $\mathrm{CO}_{2} \mathrm{uptake}\left(\mathrm{FCO} 2, \mathrm{~g} \mathrm{C} \mathrm{m}^{-2}\right)$, (c) ocean to atmosphere DMS flux (FDMS, moles DMS m ${ }^{-2}$ ), and (d) ocean to atmosphere $\mathrm{N}_{2} \mathrm{O}$ flux $\left(\mathrm{FN}_{2} \mathrm{O}, \mathrm{moles}_{2} \mathrm{O} \mathrm{m}^{-2}\right.$ ).

in the North Pacific and Atlantic, and in coastal upwelling zones (e.g., Arabian Sea, Chile-Peru upwelling). Deficiencies already identified in the comparison with SeaWiFS surface chlorophyll also translate into deficiencies in terms of $\mathrm{N}_{2} \mathrm{O}$ fluxes. This is the case in particular for the eastern Subarctic Pacific where simulated $\mathrm{N}_{2} \mathrm{O}$ fluxes are clearly underestimated. Overall, the modeled $\mathrm{N}_{2} \mathrm{O}$ annual mean flux is 3.1 Tg N y ${ }^{-1}$, which is in good agreement with the recent IPCC estimate of 3.8 $\pm 2.0 \mathrm{Tg} \mathrm{N} \mathrm{y}^{-1}$ (Denman et al., 2008).

Modeled annual-mean DMS sea-surface concentrations are compared to the climatology of Kettle and Andreae (2000) (Fig. 1d). A variety of different approaches have been use to produce sea surface DMS climatologies (see Belviso et al., 2004, for a comparison). Here, we compare our simulated DMS field to Kettle and Andreae (2000), whose climatology is based on $\sim 15000$ DMS measurements. In general agreement with the Kettle and Andreae (2000) climatology, low DMS concentrations are predicted in the subtropical gyres and higher concentrations are predicted in the Equatorial Pacific and at mid-to-high latitudes. There are however large differences between the simulated and databased climatology. DMS concentrations in the Equatorial
Pacific are largely over-estimated, as it is already the case for surface chlorophyll and $\mathrm{N}_{2} \mathrm{O}$ fluxes. In the Southern Ocean, the model predicts high concentrations in the subtropical/subantarctic convergence, similar to the estimates of Chu et al. (2003) and Simo and Dachs (2002). This pattern does not appear in the Kettle and Andreae (2000) database, but very high DMS concentrations have been measured in this convergence zone subsequently (e.g. Sciare et al., 2000). DMS concentrations are under-estimated along the Antarctic coast where the model does not represent the intense blooms of Phaeocystis, a phytoplankton group known to be a large DMS-producer. Overall, the simulated annual-mean DMS flux to the atmosphere amounts to $28.8 \mathrm{Tg} \mathrm{S} \mathrm{y}^{-1}$, in agreement with estimates by Kettle and Andreae (2000) of between 16 and $54 \mathrm{Tg} \mathrm{S} \mathrm{y}^{-1}$.

\subsection{Mixing experiments}

\subsubsection{Impact on carbon export and $\mathrm{CO}_{2}$ fluxes}

As expected, the artificial enhancement of ocean mixing in the patchy mixing experiment promotes an increase in 

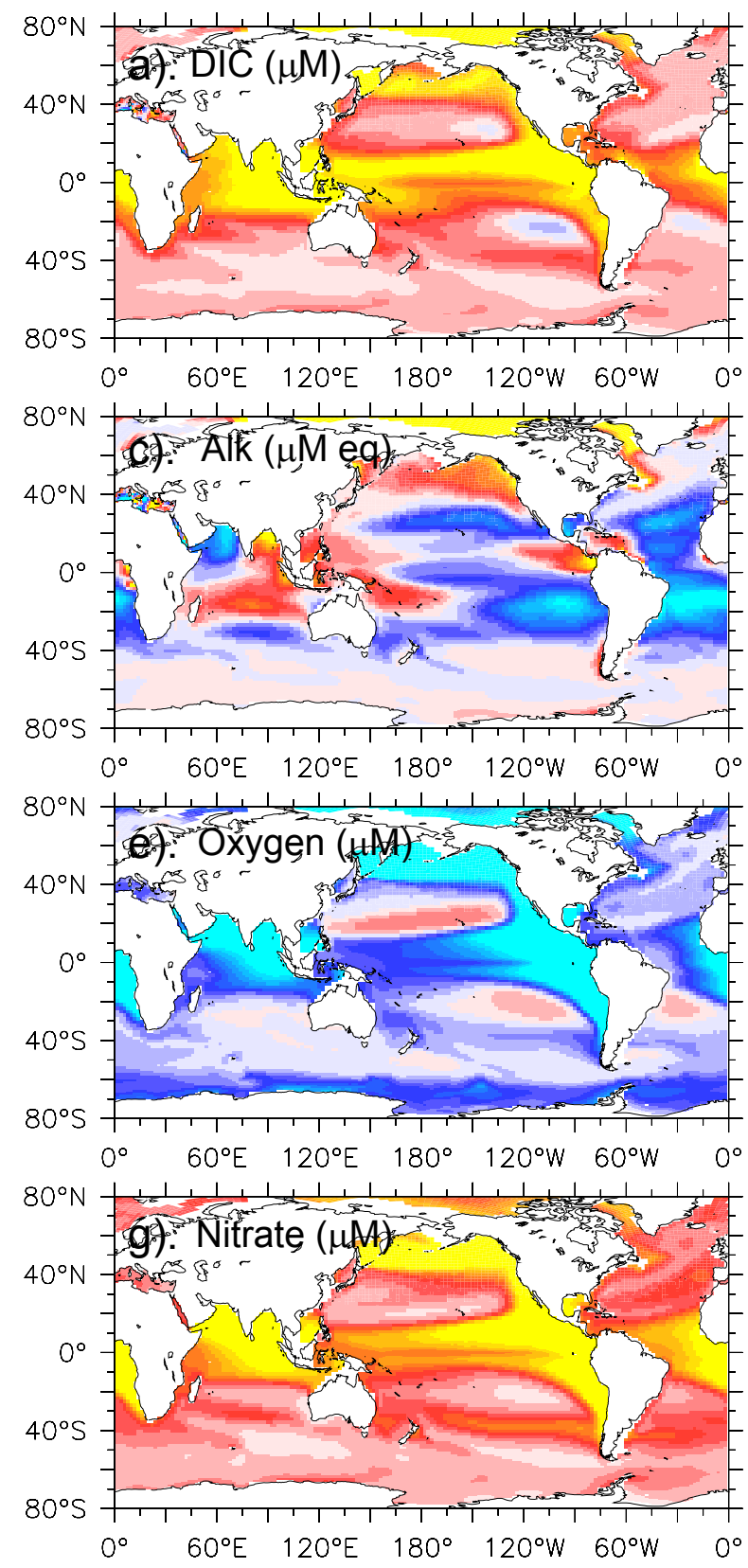
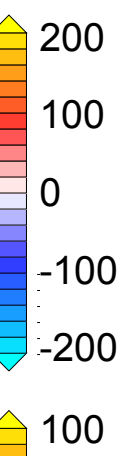

50

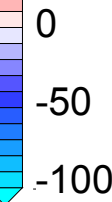

100

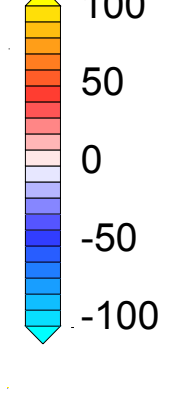

20

10

0

$-10$

$-20$
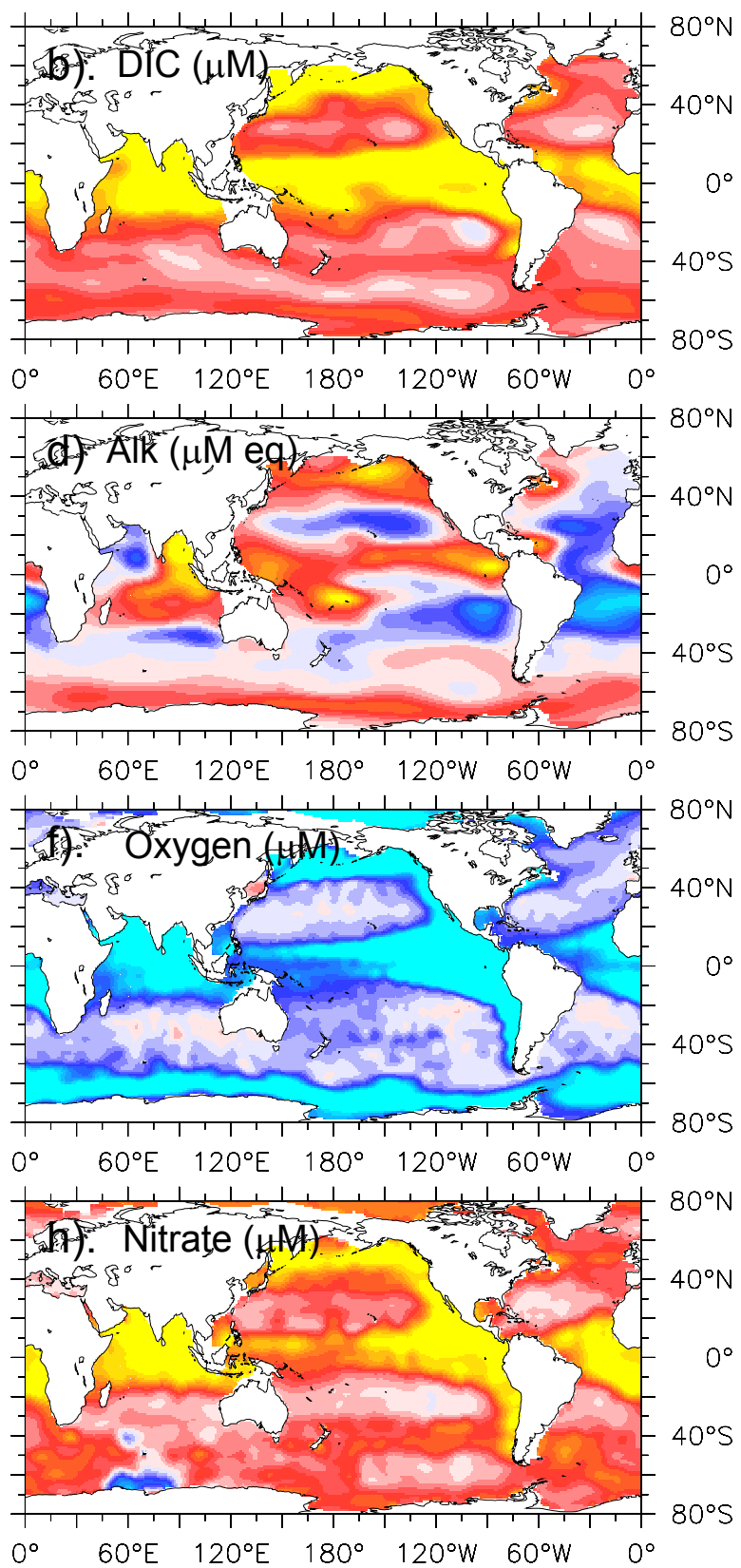

Fig. 3. The gradient (between $200 \mathrm{~m}$ and the surface) simulated by PISCES in dissolved inorganic carbon (a DIC, $\mu \mathrm{M}$ ), alkalinity (c ALK, $\mu \mathrm{M}$ eq), oxygen $\left(\mathbf{e} \mathrm{O}_{2}, \mu \mathrm{M}\right)$, nitrates $\left(\mathbf{f} \mathrm{NO}_{3}, \mu \mathrm{M}\right)$, iron (i Fe, nM), nitrous oxide $\left(\mathbf{j ~} \mathrm{N}_{2} \mathrm{O}\right.$, nM), dimethylsulfide (k DMS, nM). When available, is also displayed the same gradient from observation-based climatologies: GLODAP for DIC (b) and alkalinity (d), World Ocean Atlas for oxygen (f) and nitrates (h).

biological productivity and export of carbon (Fig. 2). The enhancement of export can be as great as $450 \mathrm{~g} \mathrm{C} \mathrm{m}^{-2} \mathrm{yr}^{-1}$, or as low as $50 \mathrm{~g} \mathrm{C} \mathrm{m}^{-2} \mathrm{yr}^{-1}$ in the equatorial Pacific and Southern Oceans (Fig. 2). In addition, non-local effects associated with the mixing that results from the lateral advection of vertically mixed water are apparent, which are most widespread in the tropical Atlantic, tropical Pacific and Indian ocean regions.
Contrary to the basic tenet of the pipe hypothesis, phytoplankton physiological processes act to dampen the impact of the additional nutrient supply on biological productivity in some oceanic regions. In contrast to non Fe limited regions, it is evident that the response of export to mixing is very weak in the Fe limited equatorial Pacific and Southern Ocean, in particular (Fig. 2). Two major processes, included in our OGCBM, are responsible for this. First, additional Fe 
causes phytoplankton to upregulate their Fe demand (Sunda and Huntsman, 1997), which is very low under the chronic Fe limitation that typically prevails. Second, the additional $\mathrm{Fe}$ promotes a shift in species composition towards diatoms (as seen during in situ experiments (de Baar et al., 2005; McAndrew et al., 2007)), which have a higher demand for Fe than nanophytoplankton. Both physiological and food web processes act in concert to increase the overall phytoplankton demand for $\mathrm{Fe}$ (the $\mathrm{Fe} / \mathrm{C}$ ratio) and results in a weak "fertilization effect" of the additional Fe supplied from mixing.

In contrast to carbon export, the air to sea $\mathrm{CO}_{2}$ flux $\left(\mathrm{FCO}_{2}\right)$ declines markedly at the site of all pipes (Fig. 2). Evidently the impact of mixing surface waters with carbon rich deep waters is greater than the additional $\mathrm{CO}_{2}$ drawdown associated with the increased biological productivity. Parallel to that seen for carbon export, we also note non-local effects on $\mathrm{FCO}_{2}$, which are generally positive (i.e., increased ocean uptake of $\mathrm{CO}_{2}$ ) at high latitudes and negative (i.e., reduced ocean uptake of $\mathrm{CO}_{2}$ ) in the tropics (Fig. 2). These patterns could be driven by either increased biological drawdown of $\mathrm{CO}_{2}$, or alkalinity anomalies in the surrounding regions.

\subsubsection{Quantifying the mechanisms that control $\mathrm{FCO}_{2}$}

Three main mechanisms control the impact of ocean pipes on $p \mathrm{CO}_{2}$ and thus $\mathrm{FCO}_{2}$. Firstly, the profile of DIC increases with depth (Fig. 3) and accordingly, increased mixing brings carbon rich deep water to the surface, which increases $p \mathrm{CO}_{2}$ and reduces $\mathrm{FCO}_{2}$. Secondly, the fertilization of biological productivity increases the consumption of DIC during photosynthesis, which reduces $p \mathrm{CO}_{2}$ and increases $\mathrm{FCO}_{2}$. Thirdly, the spatial variability of the alkalinity profile (which can be either positive or negative, Fig. 3) can either reduce or increase $p \mathrm{CO}_{2}$, depending on whether more, or less, alkalinity is provided to surface waters. All three mechanisms (DIC, biological production and alkalinity) will control the ultimate impact of mixing on $p \mathrm{CO}_{2}$ in a given oceanic region.

In Table 1, we quantify the impact of changes in DIC mixing, biological production and alkalinity (all in $\mu \mathrm{mol} \mathrm{kg}^{-1}$ ) on $p \mathrm{CO}_{2}$ (in ppm) at both the pipe location and the surrounding waters. We focus on three particular regions that highlight the interplay between the three controlling processes in governing the eventual impact on $\mathrm{FCO}_{2}$.

We first focus on the area surrounding a given pipe to account for lateral advection. In the tropical Atlantic, DIC mixing increases $p \mathrm{CO}_{2}$ by $10 \mathrm{ppm}$, but biological productivity responds greatly to the increased mixing and lowers $p \mathrm{CO}_{2}$ by approximately $5 \mathrm{ppm}$. Since tropical regions have a negative alkalinity profile (Fig. 3), mixing also reduces surface alkalinity by $3 \mu \mathrm{mol} \mathrm{kg}^{-1}$ and $p \mathrm{CO}_{2}$ increases by $4 \mathrm{ppm}$. Therefore, the net impact of mixing in the tropical Atlantic is to increase surface $p \mathrm{CO}_{2}$ by $9.6 \mathrm{ppm}$ and reduce $\mathrm{FCO}_{2}$. In the Southern Ocean we have already noted that mixing only results in a weak biological response $\left(0.17 \mu \mathrm{mol} \mathrm{kg}^{-1}\right)$ that lowers $p \mathrm{CO}_{2}$ by $0.5 \mathrm{ppm}$. However, as this region is

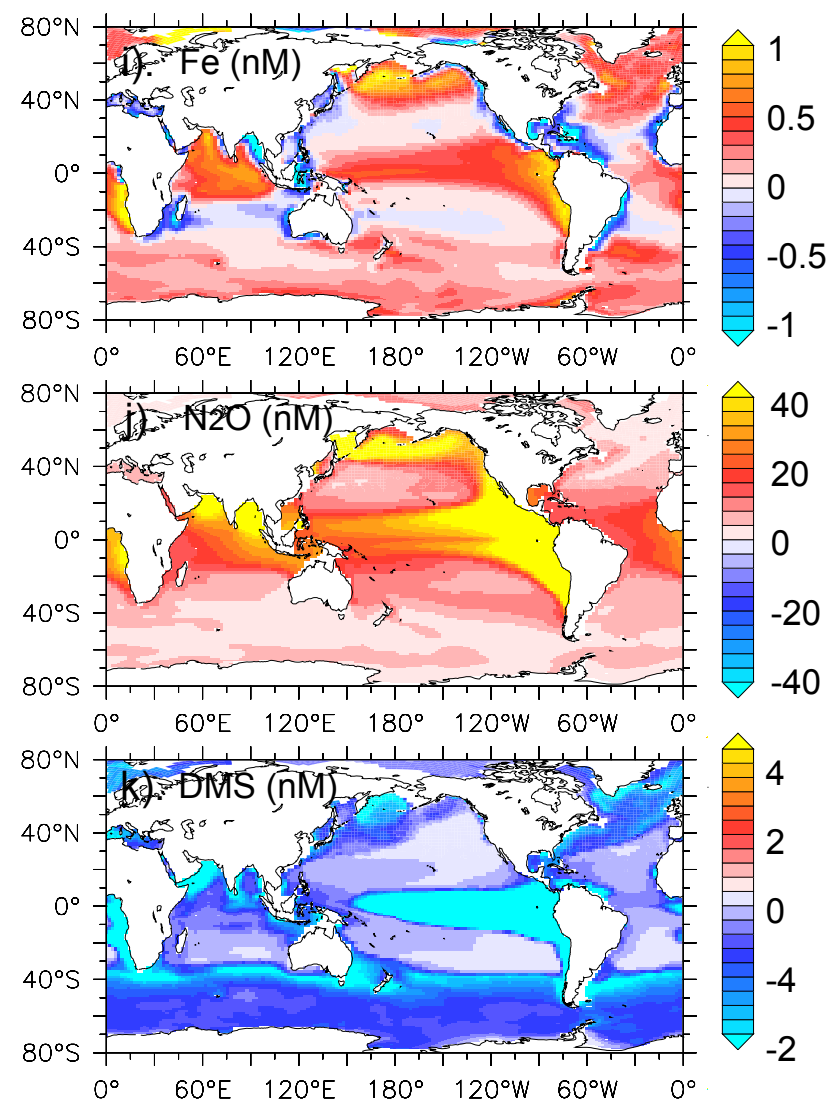

Fig. 3. Continued.

characterized by a weakly positive alkalinity profile (Fig. 3), the small increase in surface alkalinity lowers $p \mathrm{CO}_{2}$ by a further $3 \mathrm{ppm}$. Nevertheless, the greater supply of DIC contributes $\sim 7 \mathrm{ppm}$ to $p \mathrm{CO}_{2}$ and the net result is a $3.3 \mathrm{ppm}$ increase and lesser $\mathrm{FCO}_{2}$. In the sub-Arctic Pacific, we find a moderately strong biological contribution to lowering $p \mathrm{CO}_{2}$ $(-2.9 \mathrm{ppm})$ and the strongly positive alkalinity profile results in a large alkalinity increase $\left(4 \mu \mathrm{mol} \mathrm{kg}^{-1}\right)$ that reduces $p \mathrm{CO}_{2}$ by another $9.7 \mathrm{ppm}$. This increase in alkalinity means that, although extra vertical supply of DIC increases $p \mathrm{CO}_{2}$ by $12 \mathrm{ppm}$, the net effect of mixing is to slightly lower $p \mathrm{CO}_{2}$ in this region and create a sink for atmospheric $\mathrm{CO}_{2}$ (by $0.6 \mathrm{ppm}$ ). The regional heterogeneity present in the alkalinity gradient means that as the alkalinity anomaly advects laterally into the surrounding waters $\mathrm{FCO}_{2}$ increases in regions where the gradient is positive and declines where the gradient is negative (Figs. 2, 3).

If we now only examine the results at the precise pipe location, two major observations can be made. Firstly, unsurprisingly, it is clear that for all 3 processes (DIC, alkalinity and biological production) the effect is far greater at the pipe site than when evaluated over the surrounding waters (Table 1). However, it is noteworthy that the "enhancement" 
Table 1. The individual impact of changes in DIC, alkalinity, and biological export on $p \mathrm{CO}_{2}$ (in ppm), as well as the eventual $\Delta p C \mathrm{C}_{2}$ (ppm), over the surrounding waters (see Methods) for three characteristic regions (the result at the pipe location is in parentheses).

\begin{tabular}{lcccc}
\hline & \multicolumn{2}{c}{ Individual impact on $p \mathrm{CO}_{2}(\mathrm{ppm})$} & \multirow{2}{*}{ Overall $\Delta p \mathrm{CO}_{2}(\mathrm{ppm})$} \\
& $\mathrm{DIC}$ & Alkalinity & Export & \\
\hline Sub-Arctic Pacific & $+12(+284)$ & $-9.7(-69)$ & $-2.9(-19.5)$ & $-0.6(+195.5)$ \\
Tropical Atlantic & $+8.6(+95.8)$ & $+4.0(+17.9)$ & $-5.0(-15.1)$ & $+9.6(+98.6)$ \\
Southern Ocean & $+6.8(+39.2)$ & $-3.0(-11.4)$ & $-0.5(-2.0)$ & $+3.3(+25.8)$ \\
\hline
\end{tabular}

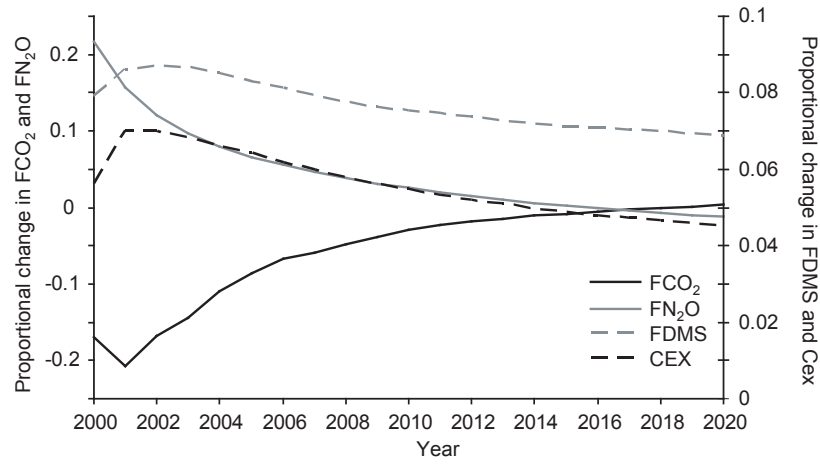

Fig. 4. The temporal evolution of the proportional difference in carbon export (Cex), and air to sea fluxes of $\mathrm{CO}_{2}\left(\mathrm{FCO}_{2}\right)$, DMS (FDMS), and $\mathrm{N}_{2} \mathrm{O}\left(\mathrm{FN}_{2} \mathrm{O}\right)$ from 2000 and 2020 in response to our patchy mixing experiment. Proportional changes in $\mathrm{FCO}_{2}$ and $\mathrm{FN}_{2} \mathrm{O}$ are on the left hand $\mathrm{y}$-axis, and the proportional changes in Cex and FDMS are on the right hand y-axis.

at the site of mixing is far greater for DIC than for alkalinity and biological production (Table 1). It appears that most DIC outgases to the atmosphere where mixing occurs, whereas alkalinity and nutrient anomalies are able advect into the surrounding waters. Accordingly, mixing is only ever beneficial (in terms of $\mathrm{FCO}_{2}$ ) because of the proximal consequences (i.e., biological production and greater alkalinity).

Overall, our analysis demonstrates that the enhancement of biological productivity is never enough to compensate for the additional supply of DIC to surface waters. It is only if sufficient alkalinity can also be added to surface waters that the effect of artificial mixing is to lower $p \mathrm{CO}_{2}$. If the addition of alkalinity occurs alongside a strong increase in carbon export, then the decrease in $p \mathrm{CO}_{2}$ will be maximal. Only the Southern Ocean and the sub-Arctic Pacific have the requisite non-negative alkalinity profile (Table 1, Fig. 3). Of these, only in the sub-Arctic Pacific is enough additional alkalinity provided to lower $p \mathrm{CO}_{2}$ and create an atmospheric $\mathrm{CO}_{2}$ sink (Table 1).

\subsubsection{Impact of mixing on atmospheric $\mathrm{CO}_{2}$, DMS and $\mathbf{N}_{2} \mathbf{O}$}

Unsurprisingly, we find that deploying an array of ocean pipes acts to increase atmospheric $\mathrm{CO}_{2}$ by $1.4 \mathrm{ppm}$ via a $5.1 \%$ reduction in cumulative $\mathrm{FCO}_{2}$, despite augmenting carbon export by $5.6 \%$. This is contrary to the expectations of Lovelock and Rapley (2007) and results from increased mixing with sub-surface DIC-rich waters (Table 1, as noted by Shepherd et al., 2007), which overwhelms any beneficial response due to increased export and alkalinity supply. The positive anomalies in biological productivity and carbon export are maximal over the first few years of the experiment and decay by 20-30\% after 20 years of deployment (Fig. 4). We further note that if we eliminate the non-local effects and mix the entire global ocean then while carbon export is over $50 \%$ greater, atmospheric $\mathrm{CO}_{2}$ increases by over $20 \mathrm{ppm}$. Accordingly, carbon export and $\mathrm{FCO}_{2}$ are clearly decoupled in response to changes in ocean mixing.

We can produce a net global ocean carbon sink if we restrict the artificial mixing to the sub-Arctic Pacific (see Methods), which was the only region where we found mixing to reduce surface ocean $p \mathrm{CO}_{2}$ (Table 1$)$. However, while we do find net uptake of atmospheric $\mathrm{CO}_{2}$, this only contributes one tenth of a ppm $\left(-0.11 \mathrm{ppm}\right.$, or $-3 \times 10^{-15} \mathrm{ppm} \mathrm{m}^{-2}$ when area-normalized) to atmospheric $\mathrm{CO}_{2}$ over 20 years. It therefore appears that even mixing favorable regions is not a very efficient way to significantly lower atmospheric $\mathrm{CO}_{2}$. For context, regional mixing experiments in the equatorial Pacific and Southern Oceans (see Methods) increase atmospheric $p \mathrm{CO}_{2}$ by $9 \times 10^{-14}$ and $7 \times 10^{-14} \mathrm{ppm} \mathrm{m}^{-2}$ (or 0.76 and $4.15 \mathrm{ppm}$ in total), respectively.

Ocean to atmosphere fluxes of DMS are increased in response to greater ocean mixing (Fig. 4). The enhancement of biological productivity causes greater production of DMS (Fig. 3), although this is somewhat reduced by the elevated diatom abundance (which produce less DMS than nanophytoplankton, (Bopp et al., 2008)) and results in a 7.7\% increase in the globally integrated cumulative DMS flux to the atmosphere over 20 years. In the Southern Ocean and equatorial Pacific, the small increase in biologically mediated DMS production (see above) means that the vertical supply of DMS-poor subsurface water (Fig. 3) causes surface 
concentrations of DMS, and hence also ocean to atmosphere fluxes, to decline (Fig. 2). Overall, the temporal evolutions of the anomalies in the DMS flux track those of biological activity, which is the dominant source term for DMS. During simulations of Fe fertilization experiments, Bopp et al. (2008) found that despite a large increase in primary production, additional biological effects associated with the Fe fertilization (i.e., increased bacterial consumption, reduced phytoplankton S/C ratio, and reduced DMSP to DMS transfer efficiency) resulted in no increase in DMS. In this study, such processes also occur and dampen the effect of increased biological activity on DMS flux to the atmosphere.

The increased $\mathrm{O}_{2}$ consumption during the remineralisation of the greater quantities of organic carbon exported to depth increases the production of the climatically important gas $\mathrm{N}_{2} \mathrm{O}$. Indeed, the 20 year cumulative $\mathrm{N}_{2} \mathrm{O}$ flux to the atmosphere increases (Figs. 2, 4) by $4.5 \%$ in response to mixing when globally integrated, which would increase radiative forcing. However, the global $\mathrm{N}_{2} \mathrm{O}$ flux exhibits a sharp decline following its initial peak and the flux anomaly reaches near zero by 2020 (Fig. 4). This is due to both an increase in the atmospheric $\mathrm{N}_{2} \mathrm{O}$ concentration that retards the air-sea gradient and an $\mathrm{O}_{2}$-driven reduction in the $\mathrm{N}_{2} \mathrm{O}$ source term in the ocean. Elevated vertical mixing drives greater mixing of high $\mathrm{O}_{2}$ surface waters with $\mathrm{O}_{2}$ poor subsurface (Fig. 3), which increases $\mathrm{O}_{2}$ concentrations (Fig. 5), especially in regions typified by high $\mathrm{N}_{2} \mathrm{O}$ fluxes (Fig. 1c). Greater concentrations of $\mathrm{O}_{2}$ reduce in situ denitrification rates and hence also the "low oxygen" pathway for the production of $\mathrm{N}_{2} \mathrm{O}$. Over decadal timescales, the increased subsurface oxygen associated with greater degrees of vertical mixing has the potential to reduce ocean sources of $\mathrm{N}_{2} \mathrm{O}$, despite an increased source in the short term (i.e., 20 years, Fig. 4). Additionally, under elevated vertical mixing, the greater subsurface concentrations of $\mathrm{NO}_{3}$ resulting from reduced denitrification will be efficiently transported to surface waters and drive reductions in surface water $\mathrm{N}_{2}$ fixation (Tagliabue et al., 2008). Although the oceanic $\mathrm{N}_{2} \mathrm{O}$ source might decline over multi-decadal timescales (especially in the equatorial Pacific, Fig. 2), it is accompanied by increasing concentrations of atmospheric $\mathrm{CO}_{2}$.

\section{Limitations of our approach}

Our study required us to simplify how we represented ocean pipes in our OGCBM. In particular, the model grid size (see Methods section) is obviously far greater than the proposed $10 \mathrm{~m}$ diameter pipes and our approach of extending the maximum vertical diffusivity to $200 \mathrm{~m}$ does not precisely represent the pumping of water from $200 \mathrm{~m}$ to the surface. However, we believe our resolution is sufficient to be able to describe and quantify the non-local effects associated with a pipe. In addition, our representation of the pumping of nutrients and other tracers, while not a direct analogue, represents the first order impact of such a process (bringing subsurface waters to the surface).

Since our OGCBM was run offline, we do not represent the impact of enhanced mixing on the profile of temperature or changes in the density structure of the newly mixed water column. Deeper waters are typically colder than those at the surface and therefore one would anticipate mixing to cool the surface waters, increasing the solubility of $\mathrm{CO}_{2}$ and reducing $p \mathrm{CO}_{2}$. On the other hand, supplying denser subsurface water to the surface, where it would overly less dense water, would destabilize and possibly further deepen the mixed layer (Lampitt et al., 2008). As we have shown, this would act to increase light limitation of photosynthesis, as well as its $\mathrm{Fe}$ demand (expressed as an increase in both chlorophyll and $\mathrm{Fe}$ to carbon ratios) and lower biological productivity.

PISCES is a relatively complex OGCBM in terms of the biological processes accounted for. As such, there are certain parameters that are necessarily unconstrained. Although we did not perform an exhaustive sensitivity analysis during this particular study, the analysis in Table 1 shows that the predominant drivers of the $p \mathrm{CO}_{2}$ response are DIC and alkalinity initial concentrations which are independent of the response of the biological activity to enhanced mixing.

In addition, although PISCES is a relatively complex OGCBM, it does not represent variability in C/N/P ratios during the production and remineralisation of organic matter. Any resulting $\mathrm{C} / \mathrm{N} / \mathrm{P}$ variability might therefore be important in governing the $\mathrm{CO}_{2}$ response to enhanced vertical mixing in oligotrophic regions that are limited by $\mathrm{N}$ and $\mathrm{P}$. That said, variability in $\mathrm{C} / \mathrm{N} / \mathrm{P}$ demands arise from complex cellular processes and adaptation (e.g., Klausmeier et al., 2004) and their inclusion in a global 3-D OGCBM is not straightforward at this stage. On the other hand, PISCES does represent variability in $\mathrm{Fe} / \mathrm{C}$ ratios (as observed by laboratory studies, e.g., Sunda and Huntsman, 1997). Accounting for this phytoplankton physiological response results in a weak export response to the increased Fe concentrations (arising from enhanced mixing) in the Southern Ocean. Finally, we also note that as more similar studies are performed using alternative OGCBMs, we will be in a position to better estimate the overall uncertainty associated with the particular modeling strategies adopted.

Since our OGCBM is not directly coupled to the climate, the role of changes in climate induced by the increased ocean outgassing of $\mathrm{CO}_{2}$, DMS, and $\mathrm{N}_{2} \mathrm{O}$ is not accounted for. For example, changes in the quantities of $\mathrm{CO}_{2}$, DMS, and $\mathrm{N}_{2} \mathrm{O}$ will impact the atmospheric heat balance and its associated dynamics, which will feedback on the ocean dynamics via modified precipitation, heat fluxes, and winds. We do, however, account for changes in flux when accounting for the concentration of atmospheric gases during the gas flux calculations (see Methods). 


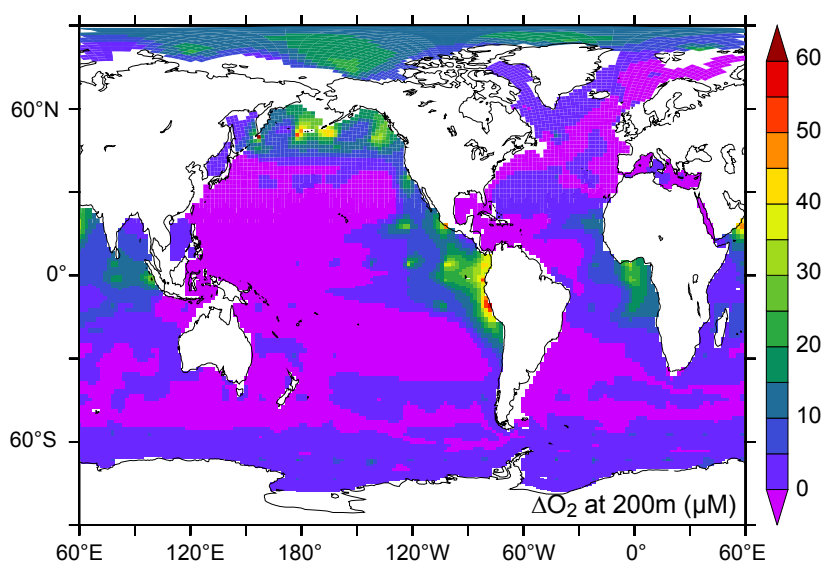

Fig. 5. The change in $\mathrm{O}_{2}$ concentration $(\mu \mathrm{M})$ at $200 \mathrm{~m}$ in 2020 in response to our patchy mixing experiment.

\section{Perspectives}

While it appears that (considering the limitations of our approach) an artificial enhancement of ocean mixing does not show great potential as a means by which we can lower atmospheric $\mathrm{CO}_{2}$ levels, our results are also important in understanding the impact of natural variability in mixing on $\mathrm{FCO}_{2}$. For example, Le Quéré et al. (2007) noted a weakening of Southern Ocean $\mathrm{FCO}_{2}$ (by $0.08 \mathrm{Pg} \mathrm{C} \mathrm{yr}^{-1}$ ), associated with increased wind driven ventilation of carbon rich deep waters. Our analyses show that the impact of enhanced mixing on Southern Ocean $\mathrm{FCO}_{2}$ is dominated by the increased surface DIC concentrations associated with greater vertical mixing and that compensatory feedbacks (in terms of $p \mathrm{CO}_{2}$ ) by alkalinity and biology are relatively weak (Table 1 ). For example, if we mix the region $40^{\circ} \mathrm{S}$ to $60^{\circ} \mathrm{S}$ to $200 \mathrm{~m}$ for 20 years, then atmospheric $p \mathrm{CO}_{2}$ increases by $4.2 \mathrm{ppm}$. Tropical regions, in particular, appear very vulnerable to mixing induced increases in surface $p \mathrm{CO}_{2}$ as, despite a more favorable productivity response, the local alkalinity profile (lower in the subsurface, Fig. 3) exacerbates the DIC driven increase in $p \mathrm{CO}_{2}$. It is for this reason that large scale upwelling systems (such as that off the coast of Peru) are typically large sources of $\mathrm{CO}_{2}$ to the atmosphere (Takahashi et al., 2008, Fig. 1). On the other hand, the strongly positive alkalinity profile in the sub-Arctic Pacific (Fig. 2) means that the increased alkalinity associated with increased mixing can potentially compensate for the increased $p \mathrm{CO}_{2}$ due to DIC increases. Accordingly, $\mathrm{FCO}_{2}$ is most vulnerable to changes in mixing in the tropics, followed by the Southern Ocean, while in sub-Arctic Pacific $\mathrm{FCO}_{2}$ is much less sensitive to mixing (as demonstrated by our regional mixing experiments).

\section{Conclusions}

We included a representation of ocean pipes that mechanically augment ocean mixing in an OGCBM to address their potential impact on carbon export and $\mathrm{CO}_{2}$ fluxes. We find that despite increasing carbon export markedly, ocean to atmosphere $\mathrm{CO}_{2}$ fluxes increase and atmospheric $\mathrm{CO}_{2}$ is greater by 2020 . The increased vertical supply of carbon rich deep water is primarily responsible for the enhanced outgassing, although increased alkalinity can compensate in the northern Pacific Ocean. Physiological processes and shifts in ecosystem composition temper the biological response in Fe limited regions such as the Southern Ocean. Even if we focus on a region where mixing is favorable, we can only create a very weak carbon sink that is not an efficient control on atmospheric $\mathrm{CO}_{2}$. While fluxes of DMS to the atmosphere do increase slightly, which might promote the formation of cloud condensation nuclei, the oceanic $\mathrm{N}_{2} \mathrm{O}$ source also expands, which would increase radiative heating of the atmosphere (alongside the increased atmospheric $\mathrm{CO}_{2}$ ). Aside from demonstrating that pipes have a limited geo-engineering potential, our study demonstrates how natural variability in mixing (such as that observed recently in the Southern Ocean) can impact $p \mathrm{CO}_{2}$ and hence $\mathrm{FCO}_{2}$ in the global ocean.

Acknowledgements. Simulations were performed at CNRS/IDRIS and CEA/CCRT, France. We thank Olivier Aumont, Sauveur Belviso, Patricia Cadule, and Corinne Le Quéré for their ideas and comments, Cynthia Nevison for providing the $\mathrm{N}_{2} \mathrm{O}$ flux database and Taro Takahashi for providing the ocean $\Delta p \mathrm{CO}_{2}$ database. This study was begun during the stay of L.B. at the University of East Anglia (UK) with the support of NERC/QUEST.

Edited by: C. Slomp

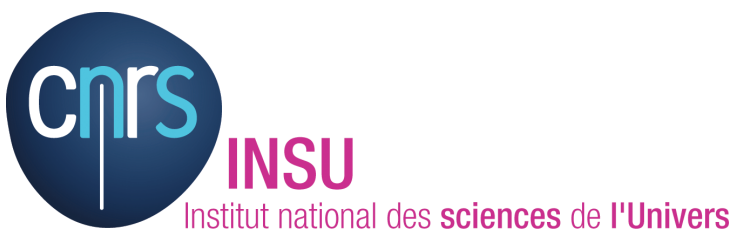

The publication of this article is financed by CNRS-INSU.

\section{References}

Arrigo, K. R. and Tagliabue, A.: Iron in the Ross Sea, Part II: Impact of discrete iron addition strategies, J. Geophys. Res., 110, C03010, doi:10.1029/2004JC002568, 2005.

Aumont, O. and Bopp, L.: Globalizing results from ocean in situ iron fertilization studies, Global Biogeochem. Cycles, 20, GB2017, doi:10.1029/2005GB002591, 2006.

Belviso, S., Bopp, L., Moulin, C., Orr, J. C., Anderson, T. R., Chu, S., Elliott, S., Maltrud, M. E., and Simo, R.: Comparison of global climatological maps of sea surface dimethylsulfide, Global Biogeochem. Cycles, 18, GB3013, doi:10.1029GB2003002193, 2004. 
Bopp, L., Aumont, O., Belviso, S., and Blain, S.: Modelling the effect of iron fertilization on dimethylsulphide emissions in the Southern Ocean, Deep-Sea Res. Part II, 55, 901-912, 2008.

Boyd, P. W., Jickells, T., Law, C. S., et al.: Mesoscale iron enrichment experiments 1993-2005: Synthesis and future directions, Science, 315(5812), 612-617, 2007.

Boyd, P. W., Watson, A. J., Law, C. S., Abraham, E. R., Trull, T., Murdoch, R., Bakker, D. C. E., Bowie, A. R., Buesseler, K. O., Chang, H., and Charette, M.: A mesoscale phytoplankton bloom in the polar Southern Ocean stimulated by iron fertilization, Nature, 407, 695-702, 2000.

Carr, M.-E., Friedrichs, M. A. M., Schmeltz, M., et al.: A comparison of global estimates of marine primary production from ocean color, Deep-Sea Res. Part II, 53, 741-770, 2006.

Chu, S., Elliott, S., and Maltrud, M. E.: Global eddy permitting simulations of surface ocean nitrogen, iron, sulfur cycling, Chemosphere, 50, 223-235, 2003.

Cullen, J. J. and Boyd, P. W.: Predicting and verifying the intended and unintended consequences of large-scale ocean iron fertilization, Mar. Ecol. Prog. Ser., 364, 295-301, 2008.

de Baar, H. J. W., Boyd, P. W., Coale, K. H., et al: Synthesis of iron fertilization experiments: From the iron age in the age of enlightenment, J. Geophys. Res., 110, C09S16, doi:10.1029/2004JC002601, 2005.

Denman, K. L., Brasseur, G., Chidthaisong, A., Ciais, P., Cox, P., Dickinson, R. E., Haugustaine, D., Heinze, C., Holland, E., Jacob, D., Lohmann, U., Ramachandran, S., da Silva Dias, P. L., Wofsy, S. C., and Zhang, X.: Couplings Between Changes in the Climate System and Biogeochemistry, p. 499-587, in: Climate Change 2007: The Physical Science Basis. Contribution of Working Group I to the Fourth Assessment Report of the Intergovernmental Panel on Climate Change, edited by: Solomon, S., Qin, D., Manning, M., Chen, Z., Marquis, M., Averyt, K. B., Tignor, M., and Miller, H. L., Cambridge University Press, Cambridge, United Kingdom and New York, NY, USA, 2007.

Dufresne, J. L., Friedlingstein, P., Berthelot, M., Bopp, L., Ciais, P., Fairhead, L., LeTreut, H., and Monfray, P.: Effects of climate change due to $\mathrm{CO} 2$ increase on land and ocean carbon uptake, Geophys. Res. Lett., 29(10), 1405, doi:10.1029/2001GL013777, 2002.

Fichefet, T. and Morales Maqueda, M. A.: Sensitivity of a global sea ice model to the treatment of ice thermodynamics and dynamics, J. Geophys. Res., 102, 12609-12646, 1997.

Fennel, K.: Widespread implementation of controlled upwelling in the North Pacific Subtropical Gyre would counteract diazotrophic N2 fixation, Mar. Ecol. Prog. Ser., 371, 301-303, 2008.

Karl, D. M. and Letelier, R. M.: Nitrogen fixation-enhanced carbon sequestration in low nitrate, low chlorophyll seascapes, Mar. Ecol. Prog. Ser., 364, 257-268, 2008.

Kettle, A. J. and Andreae, M. O.: Flux of dimethylsulfide from the oceans: A comparison of updated data sets and flux models, J. Geophys. Res., 105, 26793-26808, 2000.

Klausmeier, C. A., Litchman, E., Daufresne, T., and Levin, S. A.: Optimal N:P stoichiometry of phytoplankton, Nature, 429, 171174, 2004.

Jin, X. and Gruber, N.: Offsetting the radiative benefit of ocean iron fertilization by enhancing N2O emissions, Geophys. Res. Lett., 30, 2249, doi:10.1029/2003GL018458, 2003.

Lampitt, R. S., Achterberg, E. P., Anderson, T. R., Hughes, J. A.,
Iglesias-Rodriguez, M. D., Kelly-Gerreyn, B. A., Lucas, M., Popova, E. E., Sanders, R., Shepherd, J. G., Smythe-Wright, D., and Yool, A.: Ocean fertilization: a potential means of geoengineering?, Philos. T. R. Soc. A, 366(1882), 3919-3945, 2008.

Leinen, M.: Building relationships between scientists and business in ocean iron fertilization, Mar. Ecol. Prog. Ser., 364, 251-256, 2008.

Le Quéré, C., Rödenbeck, C., Buitenhuis, E. T., Conway, T. J., Langenfelds, R., Gomez, A., Labuschagne, C., Ramonet, M., Nakazawa, T., Metzl, N., Gillett, N., and Heimann, M.: Saturation of the Soutner Ocean CO2 sink due to recent climate change, Science, 316, 1735-1738, doi:10.1126/science.1136188, 2007.

Lovelock, J. E. and Rapley, C. G.: Ocean pipes could help the Earth to cure itself, Nature, 449-403, 2007.

McAndrew, P. M., Bjorkman, K. M., Church, M. J., Morris, P. J., Jachowski, N., Williams, P. J., and Karl, D. M.: Metabolic response of oligotrophic plankton communities to deep water nutrient enrichment, Mar. Ecol. Prog. Ser., 332, 63-75, 2007.

Madec, G., Delecluse, P., Imbard, M., and Levy, C.: OPA8.1 Ocean General Circulation Model Reference Manual, Notes du pôle de modélisation de l'IPSL, 1998.

Markels Jr., M. and Barber, R. T.: Sequestration of carbon dioxide by ocean fertilization. Paper presented at the 1st Nat Conf on Carbon Sequestration, Natl Energy Technol Lab, Washington, D.C. 14-17 May 2001.

Nakisenovic, N., Alcamo, J., Davis, G., et al.: IPCC Special Report on Emissions Scenarios, Cambridge Univ. Press, New York, 2000.

Nevison, C. D., Weiss, R. F., and Erickson, D. J.: Global oceanic emissions of nitrous oxide, J. Geophys. Res., 100, 15809-15820, 1995.

Raven, J. A.: The iron and molybdenum use efficiencies of plant growth with different energy, carbon and nitrogen sources, New Phytol., 109, 279-287, 1988.

Saltzman, E. S., King, D. B., Holmen, K., and Leck, C.: Experimental determination of the diffusion coefficient of dimethylsulfide in water, J. Geophys. Res., 98, 16481-16486, 1993.

Schlitzer, R.: Applying the adjoint method for biogeochemical modeling: Export of particulate organic matter in the World Ocean, Inverse methods in biogeochemical cycles, edited by: Kasibhata, P., AGU Monograph, 114, 107-124, 2000.

Sciare, J., Mihalopoulos, N., and Dentener, F.: Interannual variability of atmospheric dimethylsulfide in the southern indian ocean, J. Geophys. Res., 105, 26369-26377, 2000.

Shepherd, J. G., Inglesias-Rodriguez, D., and Yool, A.: Geoengineering might cause, not cure, problems, Nature, 449, 781, 2007.

Simó, R. and Dachs, J.: Global ocean emission of dimethylsulfide predicted from biogeophysical data, Global Biogeochem. Cycles, 16(4), 1078, doi:10.1029/2001GB001829, 2007.

Sunda, W. G. and Huntsman, S. A.: Interrelated influence of iron, light and cell size on marine phytoplankton growth, Nature, 390, 389-392, 1997.

Suntharalingam, P., Sarmiento, J. L., and Toggweiler, J. R.: Global significance of nitrous-oxide production and transport from oceanic low-oxygen zones: A modeling study, Global Biogeochem. Cycles, 14, 1353-1370, 2000.

Takahashi, T., Sutherland, S. C., Wanninkhof, R., et al.: Climatological mean surface $p \mathrm{CO}_{2}$ and net $\mathrm{CO}_{2}$ flux over 
the global oceans, Deep Sea Res. Part II, published online, doi:10.1016/j.dsr2.2008.12.009, 2008.

Tagliabue, A., Bopp, L., and Aumont, O.: Ocean biogeochemistry exhibits contrasting responses to a large scale reduction in dust deposition, Biogeosciences, 5, 11-24, 2008,

http://www.biogeosciences.net/5/11/2008/.

Volk, T. and Hoffert, M. I.: Ocean carbon pumps: analysis of relative strengths and efficiencies in ocean-driven atmospheric $\mathrm{CO}_{2}$ changes, in: The Carbon Cycle and Atmospheric $\mathrm{CO}_{2}$ : Natural Variations Archean to Present, edited by: Sundquist, E. T. and Broecker, W. S., pp. 99-110, Geophysical Monograph 32, American Geophysical Union, Wash., D.C., 1985.
Wanninkhof, R.: Relationship between wind speed and gas exchange over the ocean, J. Geophys. Res., 97, 7373-7382, 1992.

Zeebe, R. E. and Wolf-Gladrow, D.: $\mathrm{CO}_{2}$ in seawater: equilibrium, kinetics, isotopes, Amsterdam, The Netherlands, Elsevier, 2001. 